\title{
Arsenic trioxide induces cell cycle arrest and affects Trk receptor expression in human neuroblastoma SK-N-SH cells
}

Xilin Xiong ${ }^{1,2}$, Yang $\mathrm{Li}^{1,2^{*}}$, Ling Liu ${ }^{1,3}$, Kai Qi ${ }^{1,2}$, Chi Zhang ${ }^{1,2}$, Yueqin Chen ${ }^{1,4}$ and Jianpei Fang ${ }^{1,2}$

\begin{abstract}
Background: Arsenic trioxide $\left(\mathrm{As}_{2} \mathrm{O}_{3}\right)$, a drug that has been used in China for approximately two thousand years, induces cell death in a variety of cancer cell types, including neuroblastoma (NB). The tyrosine kinase receptor (Trk) family comprises three members, namely TrkA, TrkB and TrkC. Various studies have confirmed that TrkA and TrkC expression is associated with a good prognosis in NB, while TrkB overexpression can lead to tumor cell growth and invasive metastasis. Previous studies have shown that $\mathrm{As}_{2} \mathrm{O}_{3}$ can inhibit the growth and proliferation of a human $\mathrm{NB}$ cell line and can also affect the N-Myc mRNA expression. It remains unclear whether $\mathrm{As}_{2} \mathrm{O}_{3}$ regulates Trks for the purposes of treating NB.
\end{abstract}

Methods: The aim of the present study was to investigate the effect of $\mathrm{As}_{2} \mathrm{O}_{3}$ on Trk expression in NB cell lines and its potential therapeutic efficacy. SK-N-SH cells were grown with increasing doses of $\mathrm{As}_{2} \mathrm{O}_{3}$ at different time points. We cultured SK-N-SH cells, which were treated with increasing doses of $\mathrm{As}_{2} \mathrm{O}_{3}$ at different time points. Trk expression in the NB samples was quantified by immunohistochemistry, and the cell cycle was analyzed by flow cytometry. TrkA, TrkB and TrkC mRNA expression was evaluated by real-time PCR analysis.

Results: Immunohistochemical and real-time PCR analyses indicated that TrkA and TrkC were over-expressed in NB, and specifically during stages 1,2 and $4 \mathrm{~S}$ of the disease progression. TrkB expression was increased in stage 3 and 4 NB. $\mathrm{As}_{2} \mathrm{O}_{3}$ significantly arrested SK-N-SH cells in the G2/M phase. In addition, TrkA, TrkB and TrkC expression levels were significantly upregulated by higher concentrations of $\mathrm{As}_{2} \mathrm{O}_{3}$ treatment, notably in the 48-h treatment period. Our findings suggested that to achieve the maximum effect and appropriate regulation of Trk expression in NB stages 1, 2 and $4 \mathrm{~S}_{1} \mathrm{As}_{2} \mathrm{O}_{3}$ treatment should be at relatively higher concentrations for longer delivery times; however, for NB stages 3 and 4 , an appropriate concentration and infusion time for $\mathrm{As}_{2} \mathrm{O}_{3}$ must be carefully determined.

Conclusion: The present findings suggested that $\mathrm{As}_{2} \mathrm{O}_{3}$ induced Trk expression in SK-N-SH cells to varying degrees and may be a promising adjuvant to current treatments for NB due to its apoptotic effects.

Keywords: Arsenic trioxide, Neuroblastoma, Cell cycle, Trk expression

\footnotetext{
*Correspondence: drliyang@126.com

${ }^{1}$ Guangdong Provincial Key Laboratory of Malignant Tumor Epigenetics

and Gene Regulation, Sun Yat-Sen Memorial Hospital, Sun Yat-Sen

University, Guangzhou 510120, China

Full list of author information is available at the end of the article
} 


\section{Background}

Neuroblastoma (NB) is an extracranial solid tumor that is frequently encountered in children and accounts for $8-10 \%$ of malignancies [1]. Despite the use of intensive chemotherapy, the 5-year event-free survival is $30 \%$, and remains unsatisfactory in the high-risk and refractory NB patient subgroup [2]. The main treatment for NB includes combined chemotherapy, radiotherapy and surgery. However, despite improvements in disease progression via intensification of therapy and efforts to treat minimal residual disease, more than $50 \%$ of patients will relapse and die from their malignancies [3]. Relapsed or refractory $\mathrm{NB}$ responds poorly to conventional treatments and has a lower survival rate [4]. In recent years, new therapies, such as auto-hematopoietic stem cell transplantation (auto-HSCT), targeting and biological immunotherapy treatment, have been used somewhat effectively in patients with relapsed or refractory NB [5]; however, the efficacy remains unsatisfactory. Therefore, it is essential to identify new drugs or treatment strategies that are more efficient and result in a lower incidence of toxic side effects.

Although arsenic trioxide $\left(\mathrm{As}_{2} \mathrm{O}_{3}\right)$ is a drug that has been used in China for approximately 2000 years [6], its clinical application is limited due to its potential toxicity. In 1992, Hongde et al. [7]. demonstrated that $\mathrm{As}_{2} \mathrm{O}_{3}$ could be highly effective in the treatment of acute promyelocytic leukemia (APL), and increasing studies have shown that it can induce complete remission, even in patients with relapsed APL, at low doses and with minimal general toxicity [8]. In other studies, $\mathrm{As}_{2} \mathrm{O}_{3}$ has been shown to exert cytotoxic effects on a variety of tumors, such as lung cancer [9], nasopharyngeal carcinoma [10], osteosarcoma [11], neurogliocytoma [12], hepatoma [13], cervical cancer [14], cholangiocarcinoma [15], breast cancer [16], gastric cancer [17] and ovarian cancer [18]. These effects have been documented in vitro and in vivo. Recent studies have also shown that the growth and proliferation of a human NB cell line could be inhibited by $\mathrm{As}_{2} \mathrm{O}_{3}$ in a dose- and time-dependent manner and that $\mathrm{N}$-myc mRNA levels could also be affected [19]. Moreover, $\mathrm{As}_{2} \mathrm{O}_{3}$ inhibited NB xenograft growth in nude mice [20]. Consequently, we hypothesized that $\mathrm{As}_{2} \mathrm{O}_{3}$ could feasibly be combined with existing chemotherapeutic modalities in order to establish a new alternative treatment strategy for high-risk NB patients [20]; however, to date, there have been no reports suggesting that $\mathrm{As}_{2} \mathrm{O}_{3}$ can be a valid alternative drug for NB clinical treatment.

$\mathrm{NB}$ is characterized by clinical heterogeneity and the complexity of genetic abnormalities [21]. Recently, molecular markers, including tyrosine kinase receptors (Trks), have been shown to be capable of transforming immortalized neurons. These proteins are involved in processes such as cell differentiation, proliferation, survival and death, treatment tolerance, invasion and genetic stability [22]. The expression of various members of the Trk family at different stages is clearly related to the prognosis and outcome of NB patients [23]. In NB, the Trk family of neurotrophin receptors, which includes TrkA, TrkB and TrkC, plays a prominent role in the biological behavior and efficacy of response-related gene regulation. The activation of TrkA-I isoforms and downstream signaling by nerve growth factor (NGF) ultimately leads to the apoptosis and differentiation of NB cells [24, 25]. Numerous studies have confirmed that elevated TrkA expression in NB tumor specimens is associated with a good prognosis [25]. TrkB is activated in NB via the endogenous expression of brain-derived neurotrophic factor (BDNF), and increased TrkB expression is an indicator of poor disease prognosis, since TrkB overexpression can lead to tumor cell growth and metastasis [26]. TrkC is a high-affinity receptor for neurotrophin-3 (NT-3), and exogenous NT-3 signals promote cellular apoptosis and differentiation [27]. In the current study, a favorable NB (stage $1 / 2 / 4$ S) was characterized by high levels of TrkA and TrkC expression, while the malignant (or aggressive) form (stage 3/4) was reported to overexpress TrkB [28].

Although $\mathrm{As}_{2} \mathrm{O}_{3}$ has been associated with complicated anticancer mechanisms, including the induction of tumor cell differentiation, the inhibition of tumor cell growth and the induction of apoptosis, its efficacy in different tumors remains unclear. In APL cells, $\mathrm{As}_{2} \mathrm{O}_{3}$ exerts anti-tumor effects by acting on the PML/RARA fusion protein [29]. Furthermore the anti-tumor effects of $\mathrm{As}_{2} \mathrm{O}_{3}$ have been associated with the activation of the caspase cascade, leading to apoptotic cell death and reduced expression of the $\mathrm{Bcl}-2$ gene [30]. Gwak et al. [31]. demonstrated that $\mathrm{As}_{2} \mathrm{O}_{3}$ induced increases in p53 levels and decreases in cylinB1 levels combined with cell cycle arrest at the G2/M phase in U87MG and T98G glioblastoma cell lines. Qin et al. [32]. reported that $\mathrm{As}_{2} \mathrm{O}_{3}$ enhanced FOXO3a expression and p $27^{\text {kip } 1}$ transcription and that it may participate in the regulation of the growth of human hepatoma cells.

In the present study, immunohistochemical analysis was performed in order to examine the expression and distribution of the Trk family members during various stages of NB in children. We then examined the impact of $\mathrm{As}_{2} \mathrm{O}_{3}$ on the survival and cell cycle of NB cells. Finally, we used real-time RT-PCR in order to study changes in TrkA, TrkB and TrkC expression levels in NB cell lines following $\mathrm{As}_{2} \mathrm{O}_{3}$ treatment. The present study aimed to improve our understanding regarding the trend of TrkA, TrkB and TrkC gene expression in NB cell lines treated with $\mathrm{As}_{2} \mathrm{O}_{3}$. The findings provide experimental evidence 
regarding the exploration of the feasibility of $\mathrm{As}_{2} \mathrm{O}_{3}$ use in clinical NB treatment and can aid the assessment of chemotherapy efficacy and of long-term survival in NB children.

\section{Methods}

\section{Specimens}

A total of $12 \mathrm{NB}$ samples from patients attending the Memorial Hospital of Sun Yat-sen University were evaluated. The diagnosis of NB in these patients was reviewed by our histopathologist, and the clinical staging was assessed using the International Neuroblastoma Staging System (INSS) [33]. The present study was approved by the Institutional Ethics Committee of the Memorial Hospital of the Sun Yat-sen University. Patients and their legal guardians signed informed consent agreements to permit the use of their tumor tissue in this research.

\section{Immunohistochemistry}

Consecutive 3- $\mu \mathrm{m}$ sections were cut from every block, and an immunoperoxidase technique was implemented following antigen retrieval by either microwave treatment $\left(95{ }^{\circ} \mathrm{C}\right)$, pepsin (DAKO; Agilent Technologies, Inc., Santa Clara, CA, USA) treatment for $20 \mathrm{~min}$ and/ or citrate buffer ( $\mathrm{pH}$ 6.0) treatment for $45 \mathrm{~min}$. Following endogenous peroxidase blocking with $3 \% \mathrm{H}_{2} \mathrm{O}_{2}$-methanol for $15 \mathrm{~min}$, the specimens were rinsed with phosphatebuffered saline (PBS) for 3 times. Anti-TrkA, anti-TrkB and anti-TrkC antibodies (Abcam, Cambridge, UK) were diluted to $0.5 \mu \mathrm{g} / \mathrm{mL}$ and were used as primary antibodies. Following $12 \mathrm{~h}$ incubation at room temperature, the specimens were rinsed with PBS three times and treated for an hour at room temperature with the secondary antibody [peroxidase-conjugated anti-mouse or antirabbit antibody (Sigma-Aldrich; Merck KGaA, Darmstadt, Germany)] that was diluted to $0.5 \%$. The probes were subsequently rinsed with PBS 3 times and staining was performed using diaminobenzidine (DAB) solution (DAKO). Following drying, the samples were counterstained with Meyer hematoxylin (Sigma-Aldrich). The immunostaining of all samples was conducted under the same conditions as the antibody reaction and DAB exposure. The evaluation of Trk expression was performed by observing 20 microscope fields at $\times 100$ magnification (Santa Cruz Biotechnology, Inc., Dallas, TX, USA).

\section{Assessment of immunohistochemical staining}

The staining intensity was scored on a scale of $1-3$ as follows: 0 (absent), 1 (weak), 2 (moderate), or 3 (strong). The percentage of tumor cells that indicated positive staining was further assessed semi-quantitatively. The histochemical score (H-score) of immunoreactivity was obtained by multiplying the intensity and the percentage of positive cells, which yielded a final score of 0-300 [34]. The median expression level was selected as a cutoff value in order to classify the samples as positive or negative.

\section{Cell culture}

Human SK-N-SH cells were obtained from the Medical School of the Sun Yat-sen University. The cells were maintained in Dulbecco's modified Eagle's medium/ Nutrient Mixture F-12 Ham (DMEM/F12, 1:1 mixture) (Hyclone; GE Healthcare Life Sciences, Logan, UT, USA) supplemented with $10 \%$ heat-inactivated fetal bovine serum (Hyclone) at $37{ }^{\circ} \mathrm{C}$ in a $5 \% \mathrm{CO}_{2}$ incubator.

\section{Experimental groups}

To examine the effects of $\mathrm{As}_{2} \mathrm{O}_{3}$ on the cell cycle and the expression levels of Trk, SK-N-SH cells were divided into two treatment groups, and both groups were exposed to $4 \mu \mathrm{M} \mathrm{As}_{2} \mathrm{O}_{3}$ for $48 \mathrm{~h}$. A medium sample devoid of $\mathrm{As}_{2} \mathrm{O}_{3}$ was used as a control. To determine the effects on gene expression, the cells were cultured at three different concentrations, namely, 1, 2 and/or $4 \mu \mathrm{M}$ of $\mathrm{As}_{2} \mathrm{O}_{3}(10 \mathrm{mg}$, Beijing double-aigrettes pharmacy, China)., along with a control group for 24 and $48 \mathrm{~h}$ [2].

\section{Cell cycle distribution analysis}

The cells were seeded into 6-well plates at a density of $2.5 \times 10^{5}$ cells/well in $3 \mathrm{~mL}$ of medium and cultured overnight. Following serum starvation for $24 \mathrm{~h}$, the cells were cultivated with half maximal inhibitory concentrations (IC50s) of $\mathrm{As}_{2} \mathrm{O}_{3}$ for 24 or $48 \mathrm{~h}$ in a $37{ }^{\circ} \mathrm{C} \mathrm{CO}_{2}$ incubator. The cells were harvested by trypsinization, washed twice with PBS and fixed with cold $70 \%$ ethanol overnight. The samples were stained with propidium iodide (PI) solution containing $50 \mu \mathrm{g} / \mathrm{mL}$ RNase A and $0.1 \%$ Triton X-100. The cell cycle distribution was assessed using a flow cytometer (FCM-2012, BD, USA).

\section{Total RNA isolation}

Following $\mathrm{As}_{2} \mathrm{O}_{3}$ treatment for 48 or $72 \mathrm{~h}$, total RNA was isolated from SK-N-SH cell lines using the TRIzol reagent (Bio. Basic, Shanghai, China) according to the manufacturer's protocol. The RNA was precipitated with isopropanol, washed with $75 \%$ ethanol, and dissolved in diethylpyrocarbonate (DEPC)-treated water. The integrity and purity of total RNA were assessed by DNA gel (1\% agarose gel) electrophoresis and UV detection.

\section{Multiplex RT-PCR analysis}

Following cDNA synthesis, PCR amplification was performed in order to examine the number of Trk transcripts. The assay was carried out using a Biometra T-gradient Thermoblock thermal cycler (Gottingen, 
Germany; Table 1). Multiplex RT-PCR was conducted in a final volume of $50 \mu \mathrm{L}$ with $2 \times$ PCR-mix containing $200 \mu \mathrm{M}$ dNTPs, 5\% dimethyl sulfoxide (DMSO), $0.02 \mathrm{U}$ HotStart Taq DNA polymerase (Qiagen GmbH, Hilden, Germany), and $50 \mathrm{pmol}$ of each primer pair. The initial PCR cycle included activation of the polymerase at $95{ }^{\circ} \mathrm{C}$ for $5 \mathrm{~min}$, which was followed by 35 cycles of PCR amplification (denaturation at $95{ }^{\circ} \mathrm{C}$ for $1 \mathrm{~min}$, annealing at $55{ }^{\circ} \mathrm{C}$ for $1 \mathrm{~min}$, and elongation at $72{ }^{\circ} \mathrm{C}$ for $1 \mathrm{~min}$ ) and 1 cycle of elongation at $72{ }^{\circ} \mathrm{C}$ for $7 \mathrm{~min}$ prior to cooling at $4{ }^{\circ} \mathrm{C}$. The primer sequences are listed in Table 1 . The products from the multiplex RT-PCR were confirmed by specific Trks using individual PCRs, which were performed separately using the specific primers for each Trk. The conditions for the individual PCRs were identical to those of the multiplex reactions.

\section{Statistical analysis}

Each experiment was performed at least three times. The data are presented as the mean \pm standard deviation (SD). All data were analyzed by Student's $t$ test using the SPSS 17.0 statistical software package (SPSS, Chicago, IL, USA); a P value lower than $0.05(\mathrm{P}<0.05)$ was considered statistically significant.

\section{Results}

\section{Specimens}

The pediatric Sun Yat-sen Memorial Hospital database resulted in the identification of 12 patients diagnosed with NB; nine were stage 4 and three were stage 2 . Since the three children with stage 2 disease had lower N-myc amplification, they were classified as intermediate risk, whereas the remaining of the subjects was classified as high risk according to the INSS criteria.

\section{Neurotrophin receptor expression in NB samples}

We performed immunohistochemical analyses of Trk expression in the 12 children with NB. The distribution of Trks was tissue-specific and correlated with the clinical heterogeneity of NB. TrkA expression was present in five $(41.7 \%)$ tumors, with two (66.7\%) stage 2 and three (33.3\%) stage 4 tumors showing TrkA expression. A total of 11 (91.7\%) tumors expressed TrkB, with two (66.7\%) stage 2 and nine (100\%) stage 4 tumors. Four (33.3\%) tumors exhibited TrkC expression and were divided into two $(66.7 \%)$ stage 2 and two (22.2\%) stage 4 tumors. It is interesting to note that both TrkA (66.7\%) and TrkC $(66.7 \%)$ were strongly co-expressed in stage 2 samples, although they indicated low co-expression in stage 4 samples. Furthermore, TrkB (100\%) was highly expressed in advanced-stage disease (stage 4), whereas it was expressed to a relatively lower extent (66.7\%) in earlystage NB (stage 2) (Fig. 1).

\section{$\mathrm{As}_{2} \mathrm{O}_{3}$ induces $\mathrm{G} 2 / \mathrm{M}$ phase arrest}

Different chemotherapeutic agents have various mechanisms by which they affect cell cycle phases, including the blockade of $G_{1}-S$ and $G 2 / M$ checkpoints, the proliferative arrest, the onset of DNA repair and the activation of programmed cell death. We analyzed the cell cycle distribution of $\mathrm{As}_{2} \mathrm{O}_{3}$-treated SK-N-SH cells by flow cytometry. The cells were treated with $4 \mu \mathrm{M}$ of $\mathrm{As}_{2} \mathrm{O}_{3}$ for $48 \mathrm{~h}$, and the results of the cell cycle analyses are shown in Fig. 2. The percentage of $\mathrm{G}_{0} / \mathrm{G}_{1}$-phase cells decreased from $76.27 \%$ in control cells to $44.13 \%$ in cells treated with $4 \mu \mathrm{M} \mathrm{As} \mathrm{O}_{3}$. Concomitantly, the percentage of G2/M phase cells in the group treated with $4 \mu \mathrm{M} \mathrm{As}{ }_{2} \mathrm{O}_{3}$ $(30.93 \%)$ was significantly higher $(\mathrm{P}<0.01)$ than that noted in the control group (5.29\%). These data suggested that $\mathrm{As}_{2} \mathrm{O}_{3}$ induced apoptosis of SK-N-SH cells following cell cycle arrest at the G2/M phase (Fig. 2).

\section{$\mathrm{As}_{2} \mathrm{O}_{3}$ affects Trk mRNA expression in SK-N-SH cells}

The mRNA expression levels of TrkA, TrkB and TrkC were subsequently analyzed by RT-PCR (Fig. 3). TrkA, TrkB and TrkC were all expressed in SK-N-SH cells. TrkA levels were significantly increased in cells treated with $1 \mu \mathrm{M} \mathrm{As}_{2} \mathrm{O}_{3}$ for $48 \mathrm{~h}$ compared with those treated for $24 \mathrm{~h}(\mathrm{P}<0.01)$. In contrast to the $1 \mu \mathrm{M}$ dose of $\mathrm{As}_{2} \mathrm{O}_{3}$, TrkA was downregulated following 2 and $4 \mu \mathrm{M} \mathrm{As} \mathrm{A}_{2} \mathrm{O}_{3}$ treatment. This trend was increased at the $48-\mathrm{h}$ period compared with the 24-h period of treatment (Fig. 3a). Additional results demonstrated that the $\operatorname{TrkB}$ gene was expressed mainly in stage 3 and 4 malignant NB cells, which is consistent with previous studies [3]. TrkB expression in SK-N-SH cells increased 2.14-fold following treatment with $1 \mu \mathrm{M}$ of $\mathrm{As}_{2} \mathrm{O}_{3}$ at $48 \mathrm{~h}$, whereas $4 \mu \mathrm{M}$ treatment caused a 2.96-fold increase in expression $(\mathrm{P}<0.01)$ compared with that of the control group. $\mathrm{As}_{2} \mathrm{O}_{3}$ increased TrkB mRNA expression in a dose-dependent

Table 1 Primer sequences and expected PCR product lengths in the multiplex PCR protocol

\begin{tabular}{llll}
\hline Gene & Size $\mathbf{( b p )}$ & Upstream primer $\left(\mathbf{5}^{\prime}-\mathbf{3}^{\prime}\right)$ & Downstream primer $\mathbf{( \mathbf { 5 } ^ { \prime } \mathbf { - 3 } \mathbf { ) }}$ \\
\hline TrkA & 570 & TCCAACACGGAGGCAATC & CCAGGACATCCAGGTAGACAG \\
TrkB & 472 & TCCGAGATTGGAGCCTAACAG & CCACCAGGATCAGTTCAGACA \\
TrkC & 628 & CAAGCCCACCCACTACAACA & GTGGGACTCACTTCGTCAAAC \\
\hline
\end{tabular}




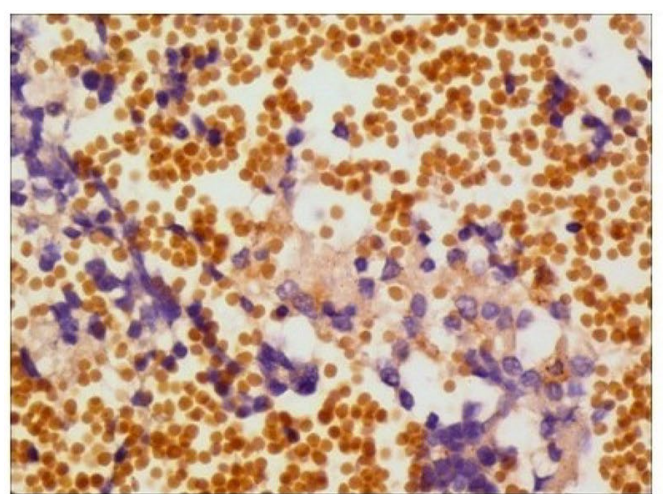

a

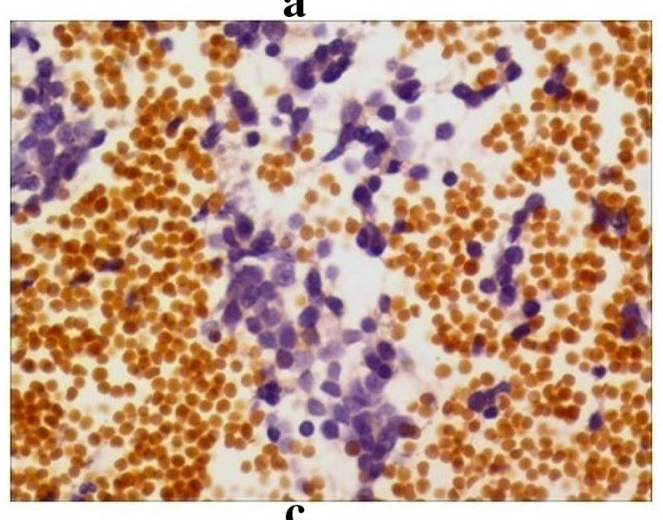

c

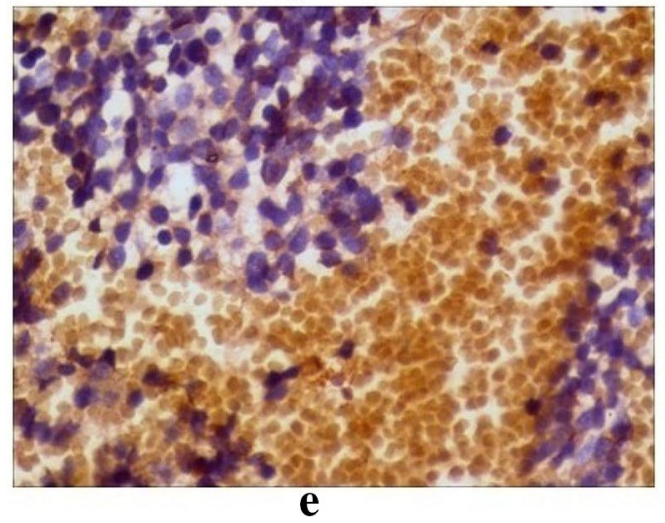

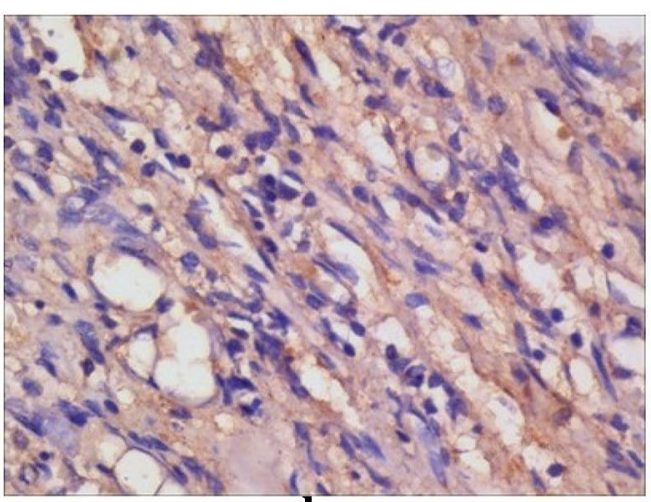

b

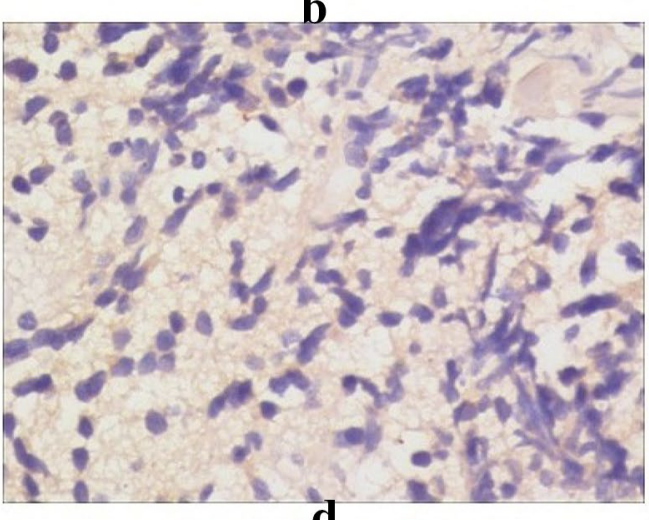

d

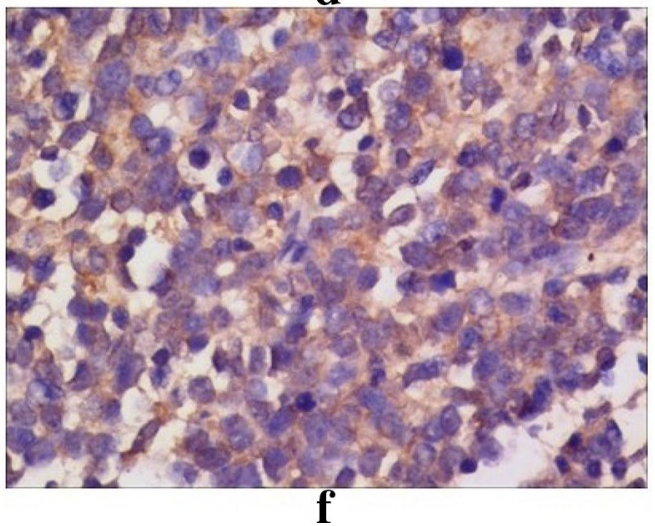

Fig. 1 Trk expression in neuroblastoma pathological tissue. Immunohistochemical analyses of TrkA, TrkB TrkC expression. Immunoreactive labeling for TrkA (a), TrkB (c) and TrkC (e) was observed in the cytoplasm of NB cells. In the control cells, TrkA (b), TrkB (d) and TrkC (f) expression was observed. Original magnification ×200. Bar $100 \mu \mathrm{m}$

manner at 24 and $48 \mathrm{~h}$. In addition, RT-PCR analyses indicated that $\mathrm{TrkC}$ expression levels were significantly higher in SK-N-SH cells treated with $4 \mu \mathrm{M} \mathrm{As}_{2} \mathrm{O}_{3}$ for $48 \mathrm{~h}$ $(5.22 \pm 0.90)$ compared with untreated cells $(1.00 \pm 0.41$, $\mathrm{P}<0.01$ ) (Fig. 3b).

\section{Discussion}

The possible prognostic factors related to the clinical behavior of NB have been identified by recent studies [35]. Trks, with their respective neurotrophin ligands, have been strongly correlated with clinical outcomes [36]. The function of these receptors is associated with the survival and differentiation of neurons in the nervous system [37]. Immunohistochemical staining for Trk expression in NB tumors demonstrated that TrkA and TrkC were expressed more prominently in stage 2 tissues. Moreover, TrkB was expressed in all stage 4 tissues, and only in some of the earlier stage tissues. Unfortunately, the present study used a low sample number and did not permit the assessment of the statistical significance of 

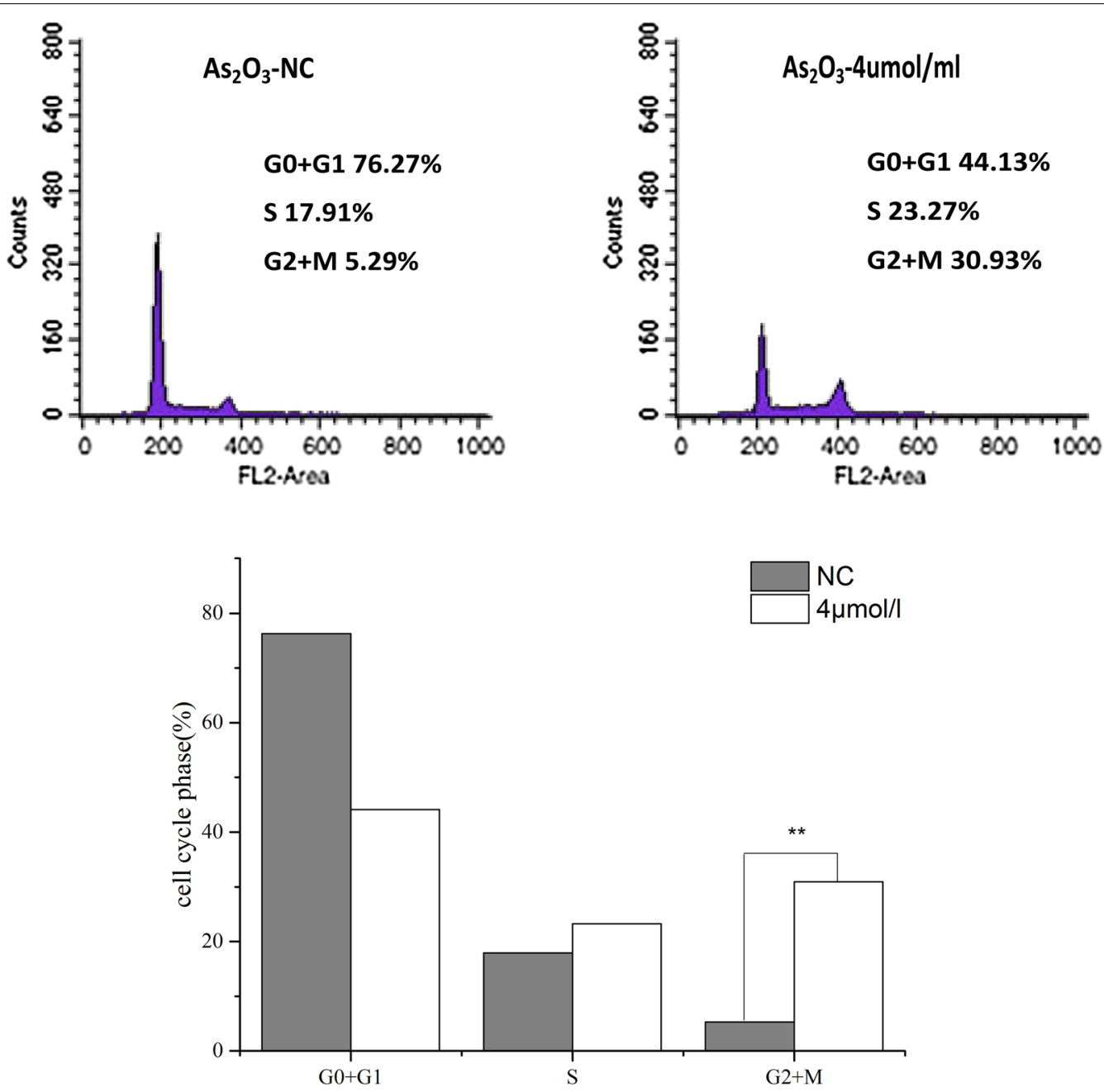

Fig. $2 \mathrm{As}_{2} \mathrm{O}_{3}$-induced S-G2/M arrest in NB cells. The effect of $\mathrm{As}_{2} \mathrm{O}_{3}$ on cell cycle distribution in SK-N-SH cells was investigated by flow cytometry following $48 \mathrm{~h}$ of treatment. The percentages of the cells in the various stages of the cell cycle were quantified

Trk distribution in tissues from different stages. Similarly, Hoehner et al. [38] assessed Trk expression at the mRNA level by real-time PCR assays and reported that TrkA and TrkC expression correlated with favorable outcomes and early stage tumor progression. TrkB was expressed in homogenates of late-stage NB patients with poor prognoses. The authors of this study postulated that in lowstage NB, TrkA and/or TrkC responsiveness may play a role in persistent tumor growth and/or regression [39]. The findings indicated that, TrkA, TrkB and TrkC should be considered new prognostic markers for NB.

$\mathrm{As}_{2} \mathrm{O}_{3}$ has been effectively used as a therapeutic agent to treat solid tumors and acts through the induction of cell cycle arrest or apoptosis [40]. Suppression of cell growth by $\mathrm{As}_{2} \mathrm{O}_{3}$ can be explained in part by its capacity to affect cell cycle distribution. Ruggeri et al. [41]. reported that low $\mathrm{As}_{2} \mathrm{O}_{3}$ concentrations $(4 \mu \mathrm{M})$ induced rapid induction of apoptosis in NB cells at a rate of more than $50 \%$ in less than 16 h. Moreover, kinase activity significantly increased in those cells treated with $4 \mu \mathrm{M}$ $\mathrm{As}_{2} \mathrm{O}_{3}$. The present study demonstrated that the treatment of SK-N-SH cells with $4 \mu \mathrm{M} \mathrm{As}_{2} \mathrm{O}_{3}$ for $48 \mathrm{~h}$ induced arrest at the G2/M phase. Our preliminary results (data not shown here) showed that the apoptosis rates of SK-N-SH cells during different time periods of $\mathrm{As}_{2} \mathrm{O}_{3}$ treatment were higher than those of the control cells. A similar study was performed by Woo et al. [42], who used SH-SY5Y and SK-N-AS NB cells co-cultured with $\mathrm{As}_{2} \mathrm{O}_{3}$. Both cell lines were arrested at the $\mathrm{S}-\mathrm{G} 2 / \mathrm{M}$ phase and this effect was associated with increased cyclin $\mathrm{B}$ expression and CDK1 activity [42, 43]. Other studies observed that the effect of $\mathrm{As}_{2} \mathrm{O}_{3}$ on cell cycle progression in NB cells may be related to the p53 status [44] and the micro-protein polymerization. These findings 

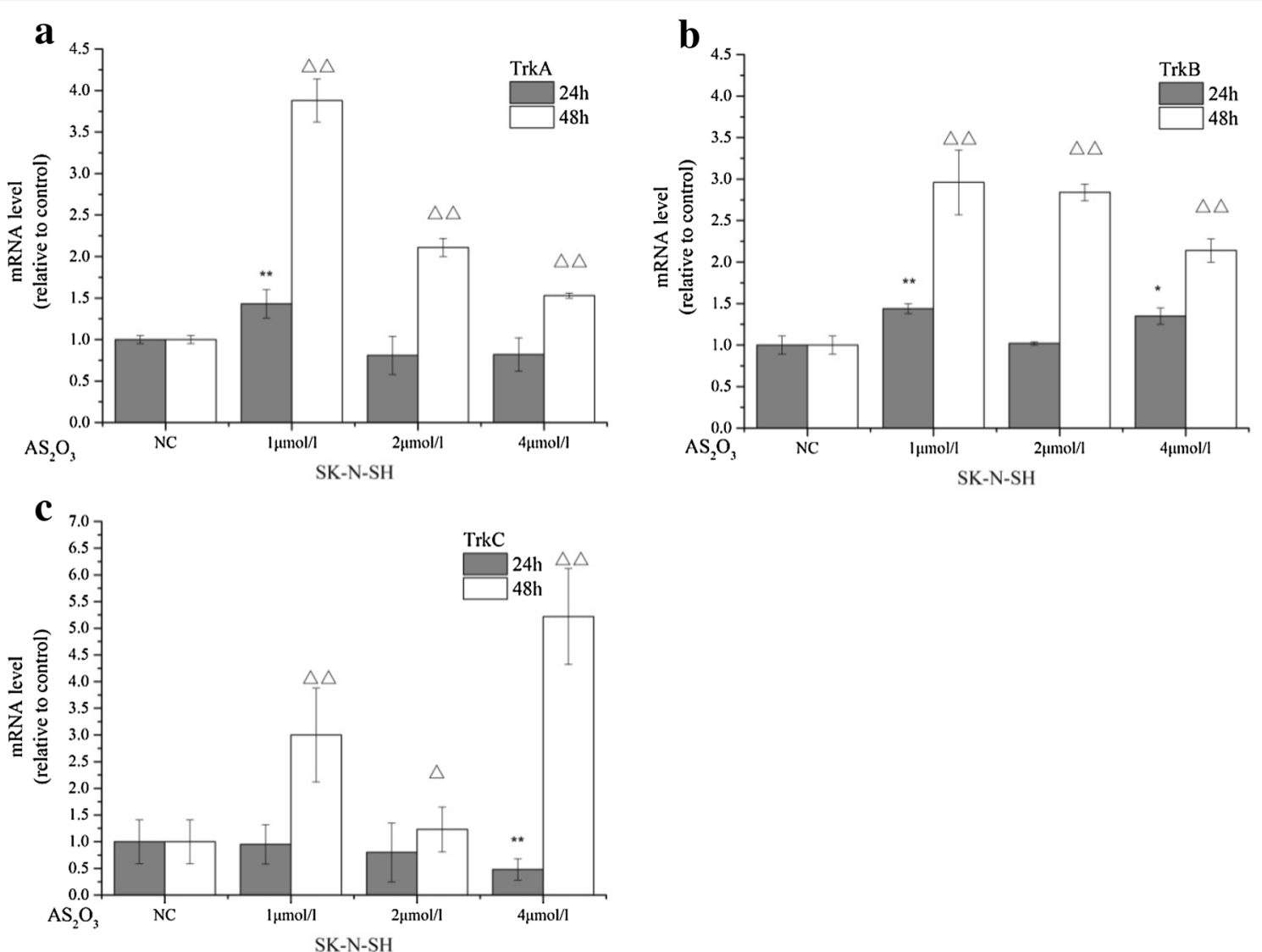

Fig. $3 \mathrm{As}_{2} \mathrm{O}_{3}$ enhances the expression of Trk genes in SH-N-SH Cells. RT-PCR was performed to analyze the mRNA expression levels of Trk genes. RT-PCR was performed on SK-N-SH cells that were treated with $0,1,2$ or $4 \mu \mathrm{M} \mathrm{As}_{2} \mathrm{O}_{3}$ for 24 or $48 \mathrm{~h}$. The data shown were compiled from three independent experiments

suggested that $\mathrm{As}_{2} \mathrm{O}_{3}$ could arrest the cell cycle by modulating the expression and/or activity of several key G2/M regulatory proteins [45]. Furthermore, the activation of caspases occurred solely in $\mathrm{As}_{2} \mathrm{O}_{3}$-induced mitotic cells only, as opposed to interphase cells [46], suggesting that $\mathrm{As}_{2} \mathrm{O}_{3}$ has a higher cytotoxicity against NB cells that are arrested at the G2/M phase. In addition, the capacity of enhancing treatment outcomes by arresting cells during the $\mathrm{S}$ phase of the cell cycle via the combination of $\mathrm{As}_{2} \mathrm{O}_{3}$ and chemotherapy should be considered.

Chemotherapeutics arrest the tumor cell cycle and further influence the expression of certain genes that closely correlate with cancer stage and prognosis [47]. The present study is the first to demonstrate that $\mathrm{As}_{2} \mathrm{O}_{3}$ can influence TrkA, TrkB and TrkC expression in a timeand dose-dependent manner. We further demonstrated that increasing $\mathrm{As}_{2} \mathrm{O}_{3}$ concentrations caused significant upregulation of TrkA and TrkC expression levels. This observation was more obvious at the $48 \mathrm{~h}$ compared with the $24 \mathrm{~h}$ time point. In human NBs, TrkA is involved in the inhibition of cell growth, the induction of apoptosis, the inhibition of angiogenesis and the determination of either apoptosis and/or differentiation [48]. The selective synthetic TrkA tyrosine kinase inhibitor $5 \mathrm{C} 3$ directly binds to the extracellular domain of TrkA and promotes receptor phosphorylation and activation of the PI3K pathway, which leads to NB cell apoptosis [49]. One report indicated that TrkC expression in tumors is often associated with favorable prognosis, suggesting that TrkC acts as a tumor suppressor and/or as a dependence receptor, regulating neuronal survival [39]. High levels of TrkA and TrkC expression in NB patients were associated with favorable prognosis; therefore, the data of the present study suggest that any treatment of NB at stages 1, 2 and $4 \mathrm{~S}$ should maintain high levels of TrkA and TrkC expression. Furthermore, the therapeutic concentration and the duration of $\mathrm{As}_{2} \mathrm{O}_{3}$ treatment should be increased.

The receptor TrkB is preferentially expressed in NB patients who have a poor prognosis and confers invasive and metastatic potential to tumor cells in addition to enhancing therapeutic resistance [50]. We further demonstrated that TrkB expression in SK-N-SH cells was 
inversely proportional to the concentration of $\mathrm{As}_{2} \mathrm{O}_{3}$, with the level of TrkB in the group treated with $4 \mu \mathrm{M}$ for $48 \mathrm{~h}$ being significantly less than that in the control group. Increased TrkB expression is believed to be associated with aggressive NB. Zhang et al. [51] demonstrated that TrkB-expressing NB cells can block cisplatin-induced cell death. Cimmino et al. [52] reported that the BDNF-mediated activation of TrkB enhanced the invasiveness and migration of NB cells in vitro, an effect that could be impaired by the transient transfection of a Gal-1-specific siRNA or a neutralizing antibody directed against Gal-1. Taken together, the data suggest that TrkB downregulation is a potential therapeutic target for refractory or relapsed NB. Our findings further suggested the use of $\mathrm{As}_{2} \mathrm{O}_{3}$ for the treatment of stage 3 and stage $4 \mathrm{NB}$, which indicate high levels of TrkB expression and poor prognoses; an appropriate concentration and treatment time for $\mathrm{As}_{2} \mathrm{O}_{3}$ remains to be determined.

\begin{abstract}
Abbreviations
$\mathrm{As}_{2} \mathrm{O}_{3}$ : arsenic trioxide; NB: neuroblastoma; Trks: tyrosine kinase receptors; auto-HSCT: auto-hematopoietic stem cell transplantation; APL: acute promyelocytic leukemia; NGF: nerve growth factor; BDNF: brain-derived neurotrophic factor; NT-3: neurotrophin-3; INSS: International Neuroblastoma Staging System; PBS: phosphate-buffered saline; IC50s: 50\% inhibitory concentrations; PI: propidium iodide; DMSO: dimethyl sulfoxide.
\end{abstract}

\section{Authors' contributions}

XX—Study design, literature research, experimental studies, data acquisition, data analysis/interpretation, manuscript preparation, manuscript editing. $Y L-$ Study concepts, study design, manuscript revision. LL-literature research, study design, data analysis. KQ-Experimental, studies, data analysis, statistical analysis. CZ-Experimental studies, data analysis. YC—Data analysis/interpretation, manuscript editing. JF-Study concepts, study design, manuscript revision. All authors read and approved the final manuscript.

\section{Author details}

${ }^{1}$ Guangdong Provincial Key Laboratory of Malignant Tumor Epigenetics and Gene Regulation, Sun Yat-Sen Memorial Hospital, Sun Yat-Sen University, Guangzhou 510120, China. ${ }^{2}$ Pediatric Hematology/Oncology, Sun Yat-Sen Memorial Hospital, Sun Yat-Sen University, Guangzhou 510120, China.

${ }^{3}$ Department of Pediatric Hematology/Oncology, Affiliated Hospital of Guangdong Medical College, Zhanjiang 524000, Guangdong, China. ${ }^{4}$ Department of Life Sciences, Sun Yat-Sen University, Guangzhou 510120, Guangdong, China.

\section{Acknowledgements}

This work was supported by the Grant 2014A030313024 from the Guang Dong Natural Science Foundation and a grant from the Guangdong Science and Technology Department (2015B050501004).

\section{Competing interests}

The authors declare that they have no competing interests. All authors have reviewed the final version of the manuscript and approve it for publication.

\section{Availability of supporting data}

The data set supporting the results of this article is included within the article.

\section{Ethics approval and consent to participate}

All procedures performed in studies involving human participants were in accordance with the ethical standards of the institutional and/or national research committee and with the 1964 Helsinki declaration and its later amendments or comparable ethical standards. Chinese Institutional Ethics Committee approval number is ChiCTR1800014748.

\section{Publisher's Note}

Springer Nature remains neutral with regard to jurisdictional claims in published maps and institutional affiliations.

Received: 14 November 2017 Accepted: 6 June 2018

Published online: 13 June 2018

\section{References}

1. Han W, Wang HM. Refractory diarrhea: a paraneoplastic syndrome of neuroblastoma. World J Gastroenterol. 2015;21(25):7929-32.

2. Bagatell R, Cohn SL. Genetic discoveries and treatment advances in neuroblastoma. Curr Opin Pediatr. 2016;28(1):19-25.

3. Kushner BH, Ostrovnaya I, Cheung IY, et al. Lack of survival advantage with autologous stem-cell transplantation in high-risk neuroblastoma consolidated by anti-GD2 immunotherapy and isotretinoin. Oncotarget. 2016;7(4):4155-66.

4. Zhu J, Wang J, Zhen ZJ, et al. Brain metastasis in children with stage 4 neuroblastoma after multidisciplinary treatment. Chin J Cancer. 2015;34(3):49.

5. La Quaglia MP. State of the art in oncology: high risk neuroblastoma, alveolar rhabdomyosarcoma, desmoplastic small round cell tumor, and POST-TEXT 3 and 4 hepatoblastoma. J Pediatr Surg. 2014;49(2):233-40.

6. Breccia M, Lo-Coco F. Arsenic trioxide for management of acute promyelocytic leukemia: current evidence on its role in front-line therapy and recurrent disease. Expert Opin Pharmacother. 2012;13(7):1031-43.

7. $\mathrm{Xu} Y, \mathrm{Chen} X$, Lin L, et al. Localization of human telomere repeat binding factor 1 in telomerase-positive and-negative cells and its expression during cell cycle. Biochimie. 2017;139:1-8.

8. Ma H, Yang J. Insights into the all-trans-retinoic acid and arsenic trioxide combination treatment for acute promyelocytic leukemia: a meta-analysis. Acta Haematol. 2015;134(2):101-8.

9. Xie SL, Yang MH, Chen $\mathrm{K}$, et al. Efficacy of arsenic trioxide in the treatment of malignant pleural effusion caused by pleural metastasis of lung cancer. Cell Biochem Biophys. 2015;71(3):1325-33.

10. Nakaoka T, Ota A, Ono T, et al. Combined arsenic trioxide-cisplatin treatment enhances apoptosis in oral squamous cell carcinoma cells. Cell Oncol (Dordr). 2014;37(2):119-29.

11. Chen J, Wei H, Cheng J, et al. Characteristics of doxorubicin-selected multidrug-resistant human leukemia $\mathrm{HL}-60$ cells with tolerance to arsenic trioxide and contribution of leukemia stem cells. Oncol Lett. 2018;15(1):1255-62.

12. Zhao HB, Sun $Q X$, Chen $X F$, et al. Efficacy of intratumoral chemotherapy using arsenic trioxide $\left(\mathrm{As}_{2} \mathrm{O}_{3}\right)$ sustained release tablets for the treatment of neurogliocytoma in nude mice. Eur Rev Med Pharmacol Sci. 2014;18(17):2453-9.

13. Che JB, Liu ZH, Ma HB, et al. Influence of $\mathrm{As}_{2} \mathrm{O}_{3}$ combined with ginsenosides Rg3 on inhibition of lung cancer NCl-H1299 cells and on subsistence of nude mice bearing hepatoma. Asian Pac J Trop Med. 2014;7(10):772-5

14. Wang H, Gao P, Zheng J. Arsenic trioxide inhibits cell proliferation and human papillomavirus oncogene expression in cervical cancer cells. Biochem Biophys Res Commun. 2014;451(4):556-61.

15. Ling $S$, Feng $T, K e ~ Q$, et al. Metformin inhibits proliferation and enhances chemosensitivity of intrahepatic cholangiocarcinoma cell lines. Oncol Rep. 2014;31(6):2611-8.

16. Kim MJ, Jung JH, Lee WS, et al. Arsenic hexoxide enhances TNF-a-induced anticancer effects by inhibiting NF-KB activity at a safe dose in MCF-7 human breast cancer cells. Oncol Rep. 2014;31(5):2305-11.

17. Gao YH, Zhang HP, Yang SM, et al. Inactivation of Akt by arsenic trioxide induces cell death via mitochondrial-mediated apoptotic signaling in SGC-7901 human gastric cancer cells. Oncol Rep. 2014;31(4):1645-52.

18. Kodigepalli KM, Anur P, Spellman P, et al. Phospholipid scramblase 1, an interferon-regulated gene located at 3q23, is regulated by SnoN/SkiL in ovarian cancer cells. Mol Cancer. 2013;12:32. 
19. Moises T, Wüller S, Saxena $S$, et al. Proteasomal inhibition alters the trafficking of the neurotrophin receptor TrkA. Biochem Biophys Res Commun. 2009:387(2):360-4

20. Ora l, Bondesson L, Jönsson C, et al. Arsenic trioxide inhibits neuroblastoma growth in vivo and promotes apoptotic cell death in vitro. Biochem Biophys Res Commun. 2000;277(1):179-85

21. Mazzocco K, Defferrari R, Sementa AR, et al. Genetic abnormalities in adolescents and young adults with neuroblastoma: a report from the Italian Neuroblastoma group. Pediatr Blood Cancer. 2015;62(10):1725-32.

22. Stasevych M, Zvarych V, Lunin V, et al. Novel anthraquinone-based derivatives as potent inhibitors for receptor tyrosine kinases. Indian J Pharm Sci. 2015;77(5):634-7.

23. Brodeur GM, Minturn JE, Ho R, et al. Trk receptor expression and inhibition in neuroblastoma. Clin Cancer Res. 2009:15(10):3244-50.

24. Fung W, Hasan MY, Loh AH, et al. Gene expression of TRK neurotrophin receptors in advanced neuroblastomas in Singapore: a pilot study. Pediatr Hematol Oncol. 2011;28(7):571-8.

25. Thress $\mathrm{K}$, Macintyre T, Wang $\mathrm{H}$, et al. Identification and preclinical characterization of AZ-23, a novel, selective, and orally bioavailable inhibitor of the Trk kinase pathway. Mol Cancer Ther. 2009:8(7):1818-27.

26. Nakamura Y, Suganami A, Fukuda M, et al. Identification of novel candidate compounds targeting TrkB to induce apoptosis in neuroblastoma. Cancer Med. 2014;3(1):25-35.

27. Werner P, Paluru P, Simpson AM, et al. Mutations in NTRK3 suggest a novel signaling pathway in human congenital heart disease. Hum Mutat. 2014;35(12):1459-68.

28. Tacconelli A, Farina AR, Cappabianca L, et al. Alternative TrkAlll splicing: a potential regulated tumor-promoting switch and therapeutic target in neuroblastoma. Future Oncol. 2005;1(5):689-98.

29. Jeanne $M$, Lallemand-Breitenbach $V$, Ferhi $O$, et al. PML/RARA oxidation and arsenic binding initiate the antileukemia response of $\mathrm{As}_{2} \mathrm{O}_{3}$. Cancer Cell. 2010;18(1):88-98.

30. Jadhav V, Ray P, Sachdeva G, et al. Biocompatible arsenic trioxide nanoparticles induce cell cycle arrest by p21(WAF1/CIP1) expression via epigenetic remodeling in LNCaP and PC3 cell lines. Life Sci. 2016;1 (148):41-52.

31. Gwak HS, Park MJ, Park IC, et al. Tetraarsenic oxide-induced inhibition of malignant glioma cell invasion in vitro via a decrease in matrix metalloproteinase secretion and protein kinase B phosphorylation. J Neurosurg. 2014;121(6):1483-91.

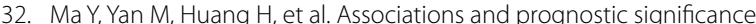
of p2 $7^{\text {Kip1 }}$ Jab1 and Skp2 in non-Hodgkin lymphoma. Mol Clin Oncol. 2016:5(4):357-64

33. Brodeur GM, Pritchard J, Berthold F, et al. Revisions of the international criteria for neuroblastoma diagnosis, staging, and response to treatment. J Clin Oncol. 1993;11(8):1466-77.

34. Torrealba N, Rodríguez-Berriguete G, Fraile B, et al. Expression of several cytokines in prostate cancer: correlation with clinical variables of patients. Relationship with biochemical progression of the malignance. Cytokine. 2017:89:105-15

35. Richter M, Dayaram T, Gilmartin AG, et al. WIP1 phosphatase as a potentia therapeutic target in neuroblastoma. PLoS ONE. 2015;10(2):e0115635.

36. Higashi M, Kolla V, lyer R, et al. Retinoic acid-induced CHD5 upregulation and neuronal differentiation of neuroblastoma. Mo Cancer. 2015;14:150.
37. Redden RA, lyer R, Brodeur GM, et al. Rotary bioreactor culture can discern specific behavior phenotypes in Trk-null and Trk-expressing neuroblastoma cell lines. Vitro Cell Dev Biol Anim. 2014:50(3):188-93.

38. Hoehner JC, Olsen L, Sandstedt B, et al. Association of neurotrophin receptor expression and differentiation in human neuroblastoma. Am J Pathol. 1995;147(1):102-13.

39. Deinhardt K, Chao MV. Trk receptors. Handb Exp Pharmacol. 2014;220:103-19

40. Kasukabe T, Okabe-Kado J, Kato N, et al. Cotylenin A and arsenic trioxide cooperatively suppress cell proliferation and cell invasion activity in human breast cancer cells. Int J Oncol. 2015;46(2):841-8.

41. Pinski J, Weeraratna A, Uzgare AR, et al. Trk receptor inhibition induces apoptosis of proliferating but not quiescent human osteoblasts. Cancer Res. 2002;62(4):986-9.

42. Woo SY, Lee MY, Jung YJ, et al. Arsenic trioxide inhibits cell growth in SH-SY5Y and SK-N-AS neuroblastoma cell lines by a different mechanism. Pediatr Hematol Oncol. 2006;23(3):231-43

43. Park JW, Choi YJ, Jang MA, et al. Arsenic trioxide induces G2/M growth arrest and apoptosis after caspase-3 activation and bcl-2 phosphorylation in promonocytic U937 cells. Biochem Biophys Res Commun. 2001;286(4):726-34

44. Yu Z, Wang R, Xu L, et al. N-(beta-Elemene-13-yl)tryptophan methyl ester induces apoptosis in human leukemia cells and synergizes with arsenic trioxide through a hydrogen peroxide dependent pathway. Cancer Lett. 2008;269(1):165-73.

45. Liu L, Li Y, Xiong $X$, et al. Low dose of arsenic trioxide inhibits multidrug resistant-related $\mathrm{P}$-glycoprotein expression in human neuroblastoma cell line. Int J Oncol. 2016;49(6):2319-30

46. Ling $\mathrm{YH}$, Jiang JD, Holland JF, et al. Arsenic trioxide produces polymerization of microtubules and mitotic arrest before apoptosis in human tumor cell lines. Mol Pharmacol. 2002:62(3):529-38.

47. Panicker J, Li Z, McMahon C, et al. Romidepsin (FK228/depsipeptide) controls growth and induces apoptosis in neuroblastoma tumor cells. Cell Cycle. 2010;9(9):1830-8

48. Wang L, Gallo KA, Conrad SE. Targeting mixed lineage kinases in ERpositive breast cancer cells leads to G2/M cell cycle arrest and apoptosis. Oncotarget. 2013;4(8):1158-71.

49. Zheng $C$, Geetha T, Gearing M, et al. Amyloid $\beta$-abrogated TrkA ubiquitination in PC12 cells analogous to Alzheimer's disease. J Neurochem. 2015:133(6):919-25.

50. Qi D, Ouyang C, Wang Y, et al. HO-1 attenuates hippocampal neurons injury via the activation of BDNF-TrkB-PI3K/Akt signaling pathway in stroke. Brain Res. 2014;1577:69-76.

51. Zhang SW, Liu X, Chan CB, et al. Amitriptyline is a TrkA and TrkB receptor agonist that promotes TrkA/TrkB heterodimerization and has potent neurotrophic activity. Chem Biol. 2009;16(6):644-56.

52. Cimmino F, Schulte JH, Zollo M, et al. Galectin-1 is a major effector of TrkB-mediated neuroblastoma aggressiveness. Oncogene. 2009:28(19):2015-23.

Ready to submit your research? Choose BMC and benefit from

- fast, convenient online submission

- thorough peer review by experienced researchers in your field

- rapid publication on acceptance

- support for research data, including large and complex data types

- gold Open Access which fosters wider collaboration and increased citations

- maximum visibility for your research: over 100M website views per year

At BMC, research is always in progress.

Learn more biomedcentral.com/submissions 